\title{
Intracellular Delivery of Doxorubicin by Iron Oxide-Based Nano-Constructs Increases Clonogenic Inactivation of Ionizing Radiation in HeLa Cells
}

\author{
Roxana Cristina Popescu ${ }^{1,2,3}$, Diana Iulia Savu ${ }^{2, * \mathbb{D}}$, Miriam Bierbaum ${ }^{1}$, Adriana Grbenicek ${ }^{1}$, Frank Schneider ${ }^{1}$, \\ Hiltraud Hosser ${ }^{4}$, Bogdan Ștefan Vasile ${ }^{3}{ }^{(0}$, Ecaterina Andronescu ${ }^{3}{ }^{\circledR}$, Frederik Wenz ${ }^{5}$, Frank A. Giordano ${ }^{1}$, \\ Carsten Herskind ${ }^{1}$ and Marlon R. Veldwijk ${ }^{1, *}$
}

Citation: Popescu, R.C.; Savu, D.I.; Bierbaum, M.; Grbenicek, A.; Schneider, F.; Hosser, H.; Vasile, B.S,.; Andronescu, E.; Wenz, F.;

Giordano, F.A.; et al. Intracellular Delivery of Doxorubicin by Iron Oxide-Based Nano-Constructs Increases Clonogenic Inactivation of Ionizing Radiation in HeLa Cells. Int. J. Mol. Sci. 2021, 22, 6778. https:// doi.org/10.3390/ijms22136778

Academic Editor: Terrence Piva

Received: 27 May 2021

Accepted: 17 June 2021

Published: 24 June 2021

Publisher's Note: MDPI stays neutral with regard to jurisdictional claims in published maps and institutional affiliations.

Copyright: (c) 2021 by the authors Licensee MDPI, Basel, Switzerland. This article is an open access article distributed under the terms and conditions of the Creative Commons Attribution (CC BY) license (https:/ / creativecommons.org/licenses/by/ $4.0 /)$.
1 Department of Radiation Oncology, Universitätsmedizin Mannheim, Medical Faculty Mannheim, Heidelberg University, 68167 Mannheim, Germany; roxana.popescu@nipne.ro (R.C.P.);

Miriam.Bierbaum@medma.uni-heidelberg.de (M.B.); Adriana.Grbenicek@medma.uni-heidelberg.de (A.G.); Frank.Schneider@umm.de (F.S.); Frank.Giordano@umm.de (F.A.G.);

Carsten.Herskind@medma.uni-heidelberg.de (C.H.)

2 Department of Life and Environmental Physics, "Horia Hulubei" National Institute for Physics and Nuclear Engineering, 077125 Magurele, Romania

3 Department of Science and Engineering of Oxide Materials and Nanomaterials, Politehnica University of Bucharest, 011061 Bucharest, Romania; Bogdan.vasile@upb.ro (B.Ș.V.); ecaterina.andronescu@upb.ro (E.A.)

4 Department of Anatomy and Developmental Biology, Center for Biomedicine and Medical Technology, Universitätsmedizin Mannheim, Medical Faculty Mannheim, Heidelberg University, 68167 Mannheim, Germany; Hiltraud.Hosser@medma.uni-heidelberg.de

5 CEO, University Medical Center Freiburg, 79106 Freiburg, Germany; Frederik.wenz@uniklinik-freiburg.de

* Correspondence: dsavu@nipne.ro (D.I.S.); Marlon.Veldwijk@medma.uni-heidelberg.de (M.R.V.); Tel.: +40214046134 (D.I.S.); +49-621-383-3750 (M.R.V.)

Abstract: In this study, we determined the potential of polyethylene glycol-encapsulated iron oxide nanoparticles $\left(\mathrm{IONP}_{\mathrm{CO}}\right.$ ) for the intracellular delivery of the chemotherapeutic doxorubicin (IONP ${ }_{\text {DOX }}$ ) to enhance the cytotoxic effects of ionizing radiation. The biological effects of IONP and X-ray irradiation (50 kV and $6 \mathrm{MV}$ ) were determined in HeLa cells using the colony formation assay (CFA) and detection of $\gamma \mathrm{H} 2 \mathrm{AX}$ foci. Data are presented as mean \pm SEM. IONP were efficiently internalized by HeLa cells. IONP ${ }_{\mathrm{CO}}$ radiomodulating effect was dependent on nanoparticle concentration and photon energy. IONP $\mathrm{CO}$ did not radiosensitize HeLa cells with $6 \mathrm{MV}$ X-rays, yet moderately enhanced cellular radiosensitivity to $50 \mathrm{kV}$ X-rays $\left(\mathrm{DMF}_{\mathrm{SF} 0.1}=1.13 \pm 0.05(p=0.01)\right)$. $\mathrm{IONP}_{\mathrm{DOX}}$ did enhance the cytotoxicity of $6 \mathrm{MV} X$-rays $\left(\mathrm{DMF}_{\mathrm{SF} 0.1}=1.3 \pm 0.1 ; p=0.0005\right)$. IONP treatment significantly increased $\gamma \mathrm{H} 2 \mathrm{AX}$ foci induction without irradiation. Treatment of HeLa cells with $\mathrm{IONP}_{\mathrm{CO}}$ resulted in a radiosensitizing effect for low-energy $\mathrm{X}$-rays, while exposure to $\mathrm{IONP}_{\mathrm{DOX}}$ induced radiosensitization compared to $\mathrm{IONP}_{\mathrm{CO}}$ in cells irradiated with $6 \mathrm{MV}$ X-rays. The effect did not correlate with the induction of $\gamma \mathrm{H} 2 \mathrm{AX}$ foci. Given these results, IONP are promising candidates for the controlled delivery of DOX to enhance the cytotoxic effects of ionizing radiation.

Keywords: radiosensitization; nanoparticles; iron oxide; polyethylene glycol; doxorubicin; drug delivery

\section{Introduction}

The current standard multimodal treatment of most cancers consists in the surgical excision of the tumor and a combination of radiotherapy and chemotherapy [1]. In order to minimize systemic adverse effects, targeted therapies involving nanoparticle-based systems have been proposed [2]. In this context, the use of iron oxide nanoparticles (IONP) is a promising approach to improve the impact of conventional chemo- and radiotherapy in treating cancer. These nanoparticles have been clinically employed in imaging $[3,4]$ and hyperthermia treatment $[5,6]$ of different cancers. 
Based on their size and magnetic properties, IONP have the ability to pass biological barriers and to be magnetically targeted towards the tumor site [7] where they can effectively deliver the active substance. In combination with radiotherapy, high- $Z$ nanoparticles such as gold have been explored as radiosensitizers due to the release of high-intensity, low-energy electrons from their surfaces. IONP with intermediate $Z$ can also potentially induce the production of secondary reactive species [8] which can lead to the alteration of metabolic function, DNA damage, protein expression, division or even to induction of cell death $[9,10]$. However, some nano-systems such as encapsulated IONP have the added advantage of being able to directly deliver cytotoxic or radiosensitizing compounds.

The sensitizing response is not only dependent on the physico-chemical characteristics of the used nanoparticles, such as composition [11-13], dimension [14,15], surface area [16,17], coating [17-20], but also influenced by their targeting ability and intracellular localization $[14,17,21-24]$, as well as by radiation type and properties, such as energy, dose, and flow $[17,25]$.

The aim of this study was to use core-shell polyethylene glycol-encapsulated IONP $\left(\mathrm{IONP}_{\mathrm{CO}}\right)$ to load the chemotherapeutic substance doxorubicin (DOX) (IONP ${ }_{\mathrm{DOX}}$ ), in order to obtain radiosensitizing effects in human cervical adenocarcinoma cells (HeLa) at different doses and energies of the ionizing radiation. IONP are able to generate highly genotoxic reactive oxygen species due to the Fenton reaction and Haber-Weiss cycle [26]. Additionally, the combined effect of DOX with radiation has been previously employed clinically [27-31], its controlled delivery using nanoparticles promising to reduce the reported systemic toxic effects [32-37].

To the best of our knowledge, a drug delivery system based on iron oxide nanoparticles encapsulated in a polyethylene glycol shell has never been used before for radiosensitization purposes. In addition, drug-free polyethylene glycol-encapsulated iron oxide nanoparticles proved to have radiomodulatory effects in HeLa cells exposed to low-energy $\mathrm{X}$-ray radiation treatment, which is reported here for the first time.

\section{Results}

Polyethylene glycol-encapsulated iron oxide nanoparticles $\left(\mathrm{IONP}_{\mathrm{CO}}\right)$ were synthesized to encapsulate the anthracycline doxorubicin $\left(\mathrm{IONP}_{\mathrm{DOX}}\right)$. High-resolution transmission electron microscopy (HR-TEM) demonstrated that round crystalline nanoparticles with core-shell morphology were produced (Figure 1A,B). The crystallinity was confirmed by selected-area electron diffraction (SAED), which displayed diffraction rings characteristic of magnetite crystalline planes (Figure 1C): (220), (222), (400), (422), (333), (440).

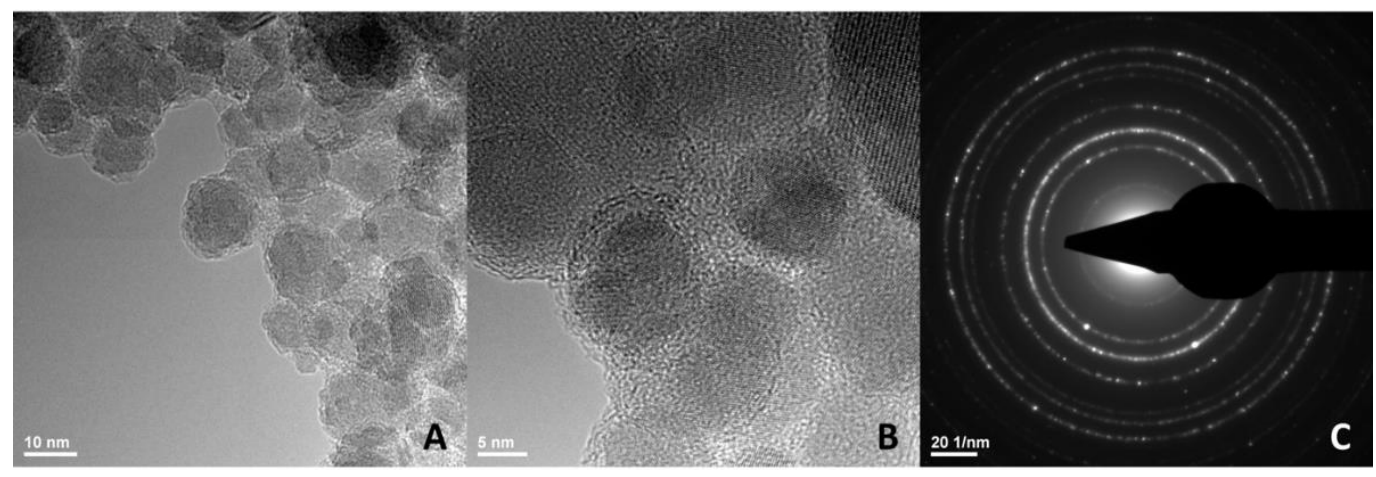

Figure 1. (A,B) High-resolution transmission electron microscopy (HR-TEM) at different magnifications and (C) selectedarea electron diffraction (SAED) of IONP.

The biological effects of IONP were determined for human cervical adenocarcinoma cells (HeLa). Optical, fluorescence, and electron microscopy confirmed the successful and efficient internalization of the IONP in HeLa tumor cells after $16 \mathrm{~h}$ of incubation, as well as their localization in the peri-nuclear area (Figures 2 and 3), as described previously [38]. 


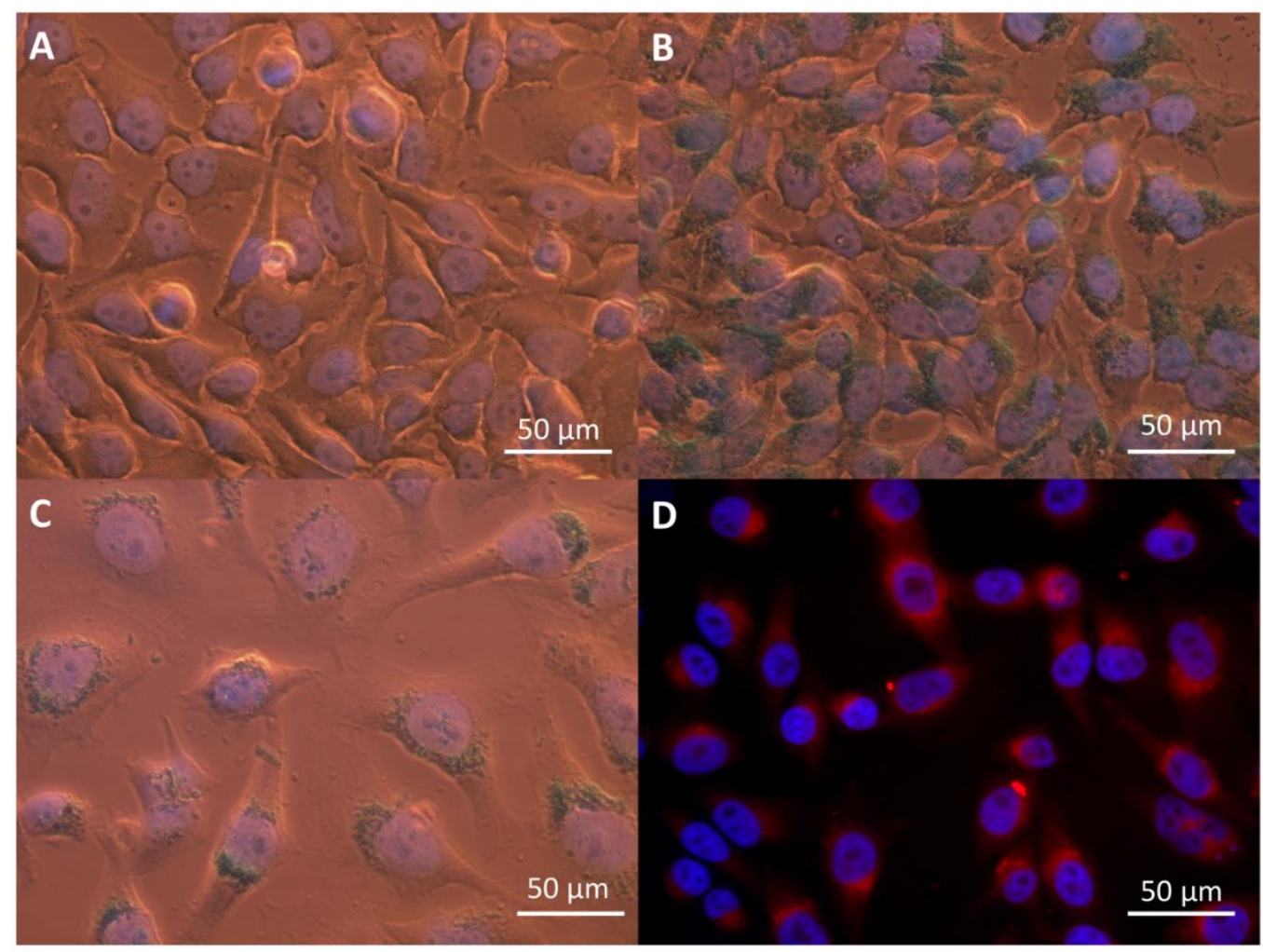

Figure 2. Internalization of IONP in HeLa cells: (A) control, (B) $100 \mu \mathrm{g} / \mathrm{mL} \mathrm{IONP} \mathrm{CO}_{\text {, and }}$ (C,D) $100 \mu \mathrm{g} / \mathrm{mL}$ IONP DOX $_{\text {; }}$ (A-C) optical microscopy images, Prussian blue counterstaining of Fe and DAPI staining of nuclei; (D) fluorescence microscopy images, DAPI staining of nuclei (blue) and DOX auto-fluorescence (red).

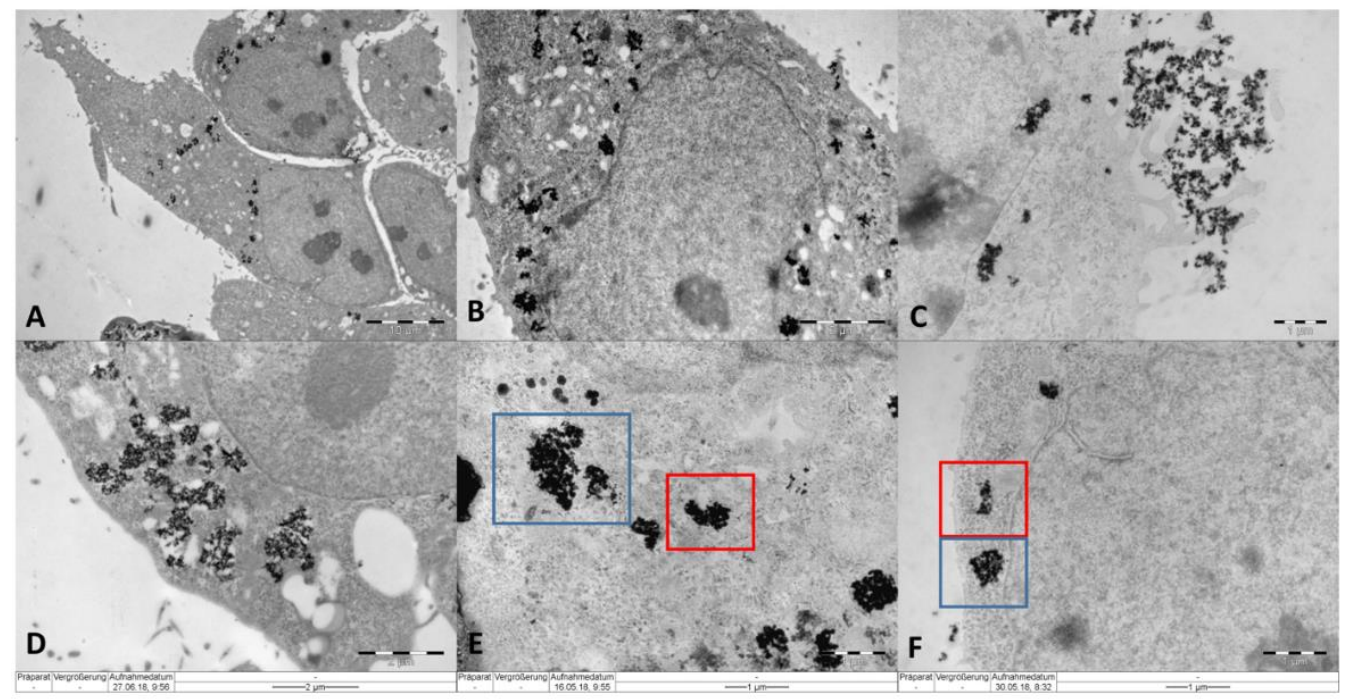

Figure 3. Internalization of (A) $\mathrm{IONP}_{\mathrm{CO}}$, (B) $\mathrm{IONP}_{\mathrm{DOx}}$ in HeLa cells in a peri-nuclear pattern; (C) macropinocytosis of IONP; (D) localization of IONP $\mathrm{CO}$ in vesicle structures; (E,F) localization of $\mathrm{IONP}_{\mathrm{DOX}}$ in the cytoplasm (blue square) and their exit from a vesicle structure (red square). The cells were incubated for $16 \mathrm{~h}$ with $100 \mu \mathrm{g} / \mathrm{mL}$ IONP.

Analysis of proliferation (MTT assay; Figure 4) showed an initial (48/72 h) decrease in proliferation for all groups compared to untreated controls, irrespective of IONP concentra-

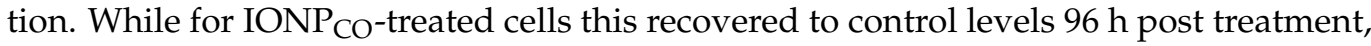
for IONP ${ }_{\mathrm{DOX}}$-treated cells, this difference remained significant $(p \leq 0.01)$, irrespective of IONP concentration. 


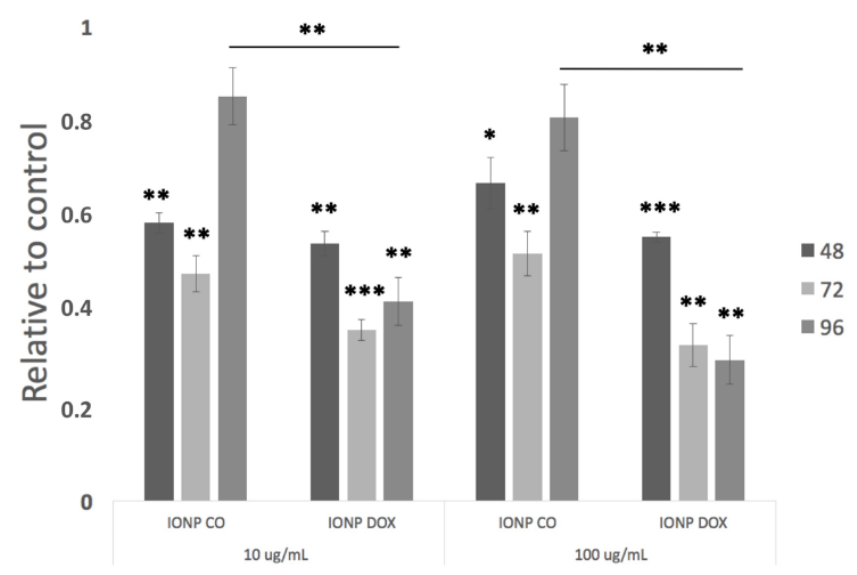

Figure 4. Proliferation of HeLa cells after incubation with different concentrations $(10,100 \mu \mathrm{g} / \mathrm{mL})$ of IONP up to $96 \mathrm{~h}$. Data are presented relative to untreated control cells and as mean $\pm \mathrm{SEM}(\mathrm{n}=3)$; ${ }^{*} p<0.05,{ }^{* *} p \leq 0.01$ and ${ }^{* * *} p \leq 0.001$.

The radiomodulating effect of IONP was investigated for low- $(50 \mathrm{kV})$ and high(6 MV) energy X-ray irradiation. We found that $50 \mathrm{kV} \mathrm{X-rays} \mathrm{with} \mathrm{a} \mathrm{mean} \mathrm{photon} \mathrm{energy}$ in the range just above the $\mathrm{K}$ - absorption edge of iron $(7.1 \mathrm{keV})$ induced a small but significant radiosensitizing effect of $100 \mu \mathrm{g} / \mathrm{mL}$ IONP $_{\mathrm{CO}}$ in HeLa cells (Figure 5). The dose-modifying factor calculated for a survival fraction of 0.1 was $\mathrm{DMF}_{\mathrm{SF} 0.1}=1.13 \pm 0.05$ $(p=0.01, \mathrm{n}=3)$. $\gamma \mathrm{H} 2 \mathrm{AX}$ repair foci (a surrogate marker for DNA double-strand break induction and repair) were increased $8.78 \pm 2.91$-fold $(p<0.001 ; 4$ Gy control vs. 0 Gy control) $30 \mathrm{~min}$ after irradiation with a single dose of $4 \mathrm{~Gy}$, and some residual foci remained at $24 \mathrm{~h}$ indicating that DNA double-strand break repair was not complete (NS; Figure 6A). Similarly, $\gamma \mathrm{H} 2 \mathrm{AX}$ foci were induced 30 min after $4 \mathrm{~Gy}$ of $6 \mathrm{MV}$ X-rays (Figure $6 \mathrm{~B}$ ), although the level seemed slightly lower than for $50 \mathrm{kV}$, but in this case, few residual foci remained $24 \mathrm{~h}$ after irradiation (Figure 6A).
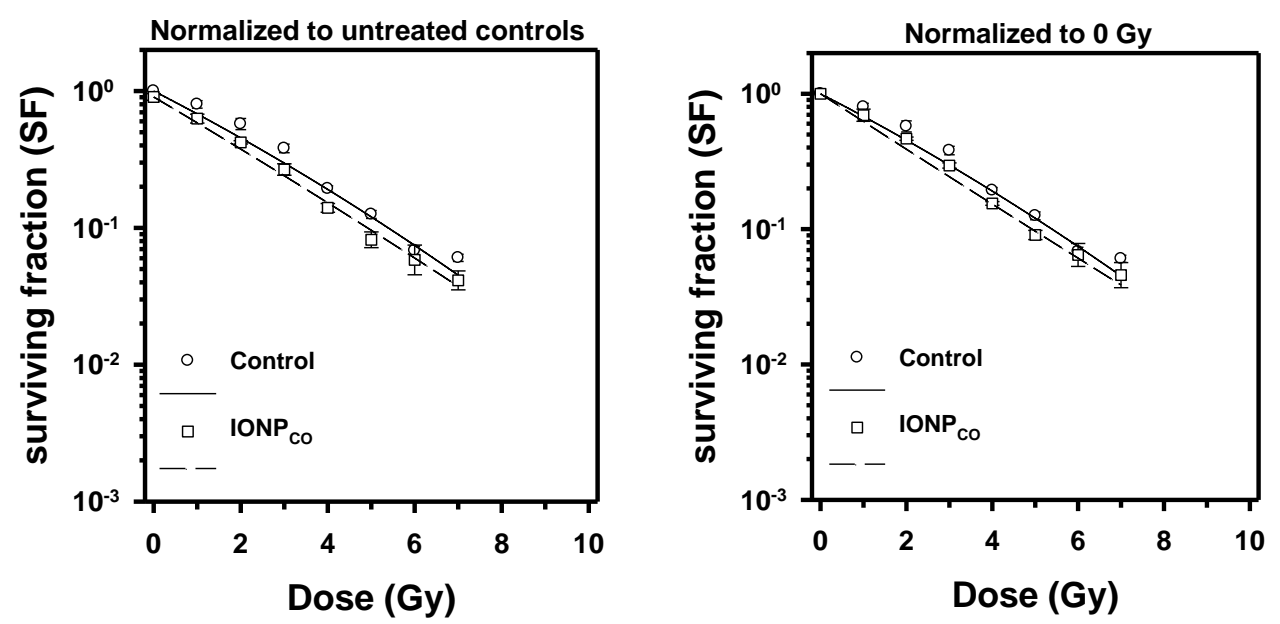

Figure 5. Clonogenic survival of HeLa cells after exposure to $100 \mu \mathrm{g} / \mathrm{mL}$ IONPs for $16 \mathrm{~h}$, followed by $50 \mathrm{kV}$ X-ray treatment. Data are presented as mean $\pm \operatorname{SEM}(\mathrm{n}=3)$.

$\mathrm{IONP}_{\mathrm{CO}}$ treatment at 10 or $100 \mu \mathrm{g} / \mathrm{mL}$ followed by $6 \mathrm{MV}$ X-rays yielded less steep survival curves characterized by a stronger downward curvature than for $50 \mathrm{kV} X$-rays. However, IONP $\mathrm{CO}$ did not induce significant radiosensitization (Figure 7).

Incubation with DOX-loaded IONP (IONP $\left.{ }_{\mathrm{DOX}}\right)$ prior to radiation treatment induced a radiomodulatory effect dependent on the nanoparticle concentration (Figure 7). Treatment with $10 \mu \mathrm{g} / \mathrm{mL} \mathrm{IONP}_{\text {DOx }}$ prior to irradiation with $6 \mathrm{MV}$ irradiation did not result in a significant radiosensitization of the cells (Figure 7A). However, $100 \mu \mathrm{g} / \mathrm{mL} \mathrm{IONP}_{\text {DOX }}$ caused a significant decrease in cell survival at 2 and $4 \mathrm{~Gy}$ (IONP $\mathrm{DOX}_{\text {vor }}$ control: $p=0.009$ 
(2 Gy) and $p=0.02$ (4 Gy); Figure 7B). The dose-modifying factor of IONP ${ }_{\text {DOx }}$ previous exposure to radiation therapy was $\mathrm{DMF}_{\mathrm{SF} 0.1}=1.30 \pm 0.10(p<0.001)$.

A

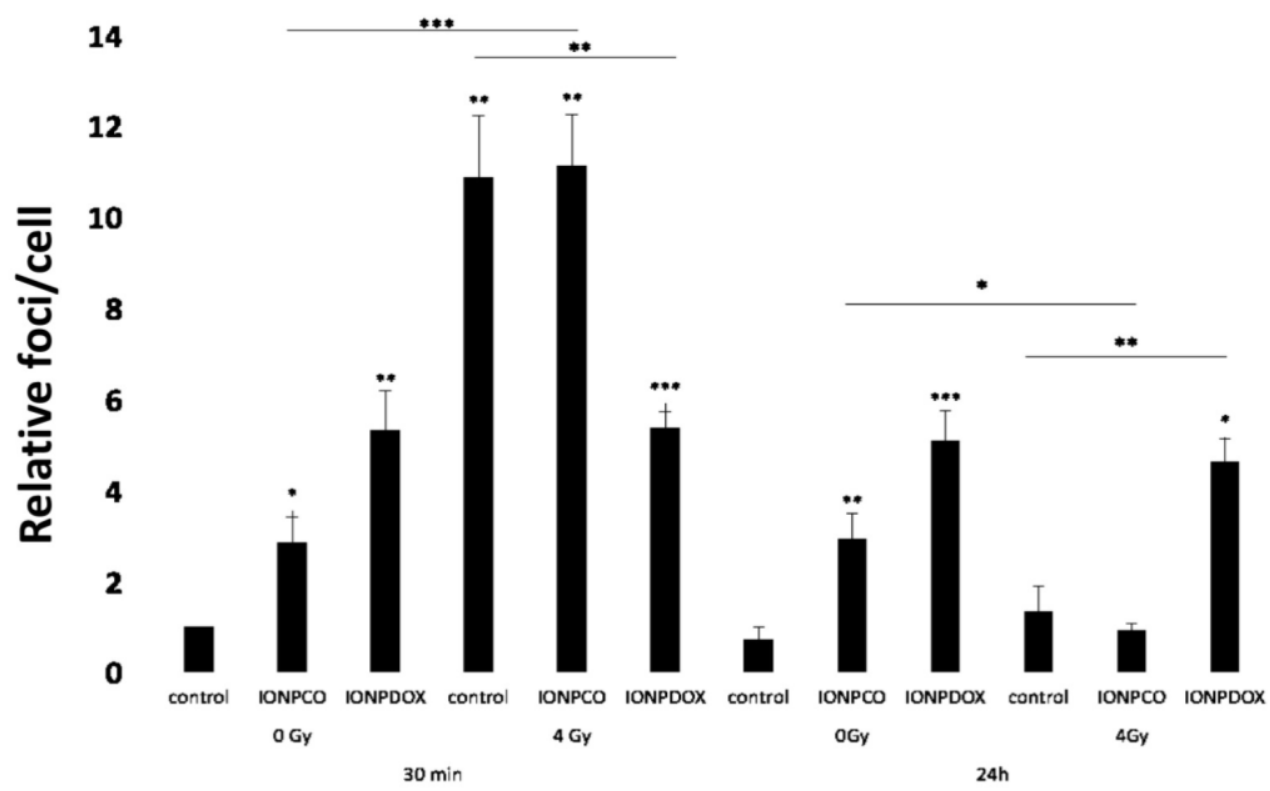

B

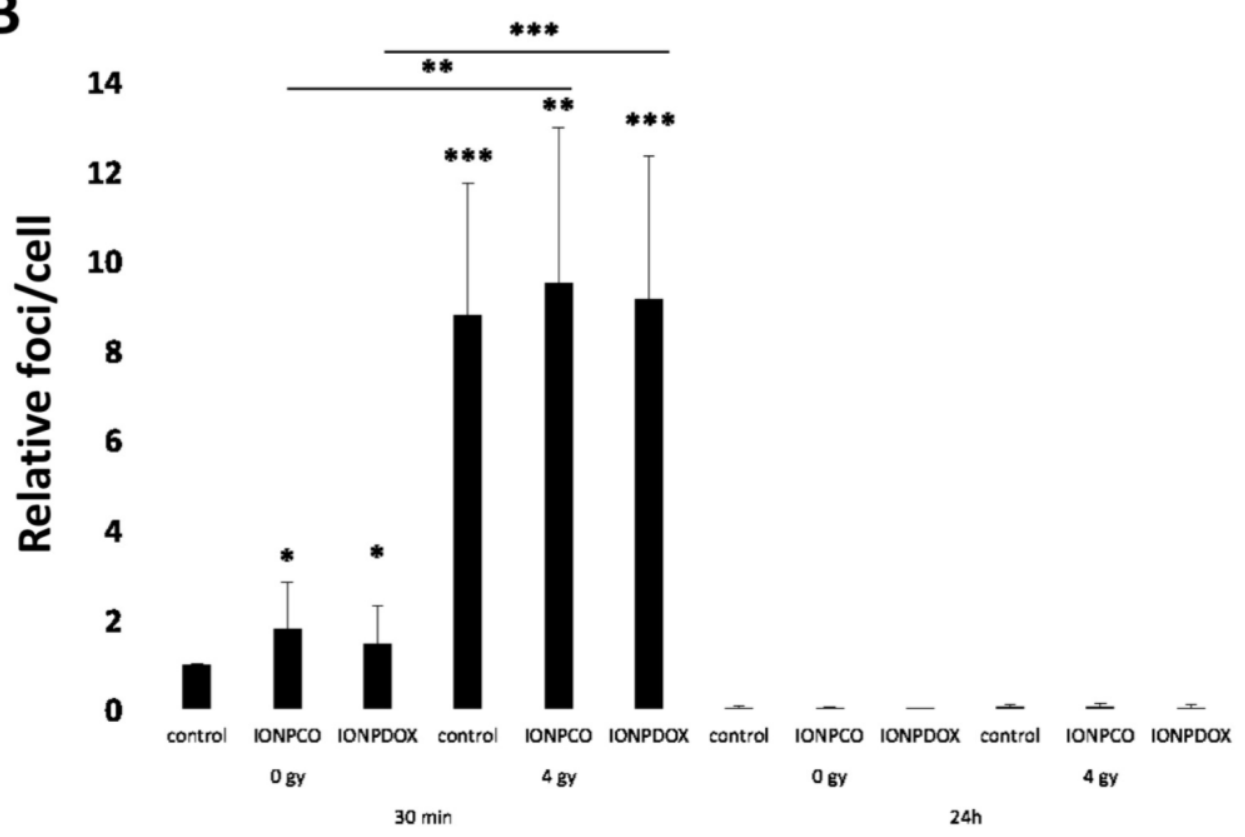

Figure 6. Double-strand DNA damage measured by $\gamma \mathrm{H} 2 \mathrm{AX}$ foci detection after $100 \mu \mathrm{g} / \mathrm{mL}$ IONP treatment for $16 \mathrm{~h}$ and/or $4 \mathrm{~Gy}$ and $50 \mathrm{kV}$ (A) $6 \mathrm{MV}$ (B) X-ray irradiation; the analysis was performed $30 \mathrm{~min}$ and $24 \mathrm{~h}$ after irradiation. Data are presented as relative foci per cell (versus the control group) and mean $\pm \operatorname{SEM}(\mathrm{n}=3) ;{ }^{*} p<0.05,{ }^{* *} p \leq 0.01$ and ${ }^{* * *} p \leq 0.001$.

$\mathrm{IONP}_{\mathrm{DOX}}$ alone resulted in a significant induction of $\gamma \mathrm{H} 2 \mathrm{AX}$ foci, compared to control cells after $16 \mathrm{~h}$ of incubation (Figure 6). However, irradiation with either $50 \mathrm{kV}$ (Figure 6A) or $6 \mathrm{MV}$ (Figure $6 \mathrm{~B}$ ) X-rays negated this effect (30 min after irradiation). Residual foci were noticed in the case of cells treated with $\mathrm{IONP}_{\mathrm{DOX}}$ and $50 \mathrm{kV}$; however, the effect was induced rather by nanoparticles than by radiation $\left(\mathrm{IONP}_{\mathrm{DOx}} 0 \mathrm{~Gy}\right.$ vs. $\mathrm{IONP}_{\mathrm{DOx}} 4 \mathrm{~Gy}$ : NS, Figure $6 B$ ). This suggests that the reduced surviving fraction of HeLa cells treated 
with IONP $\mathrm{DOX}_{\mathrm{D}}$ might be due to an additive cytotoxicity of DOX when using $6 \mathrm{MV}$ X-rays $\left(\mathrm{IONP}_{\mathrm{DOX}}\right.$ vs. $\mathrm{IONP}_{\mathrm{CO}}: p<0.05$ at all doses; Figure 7$)$.

A
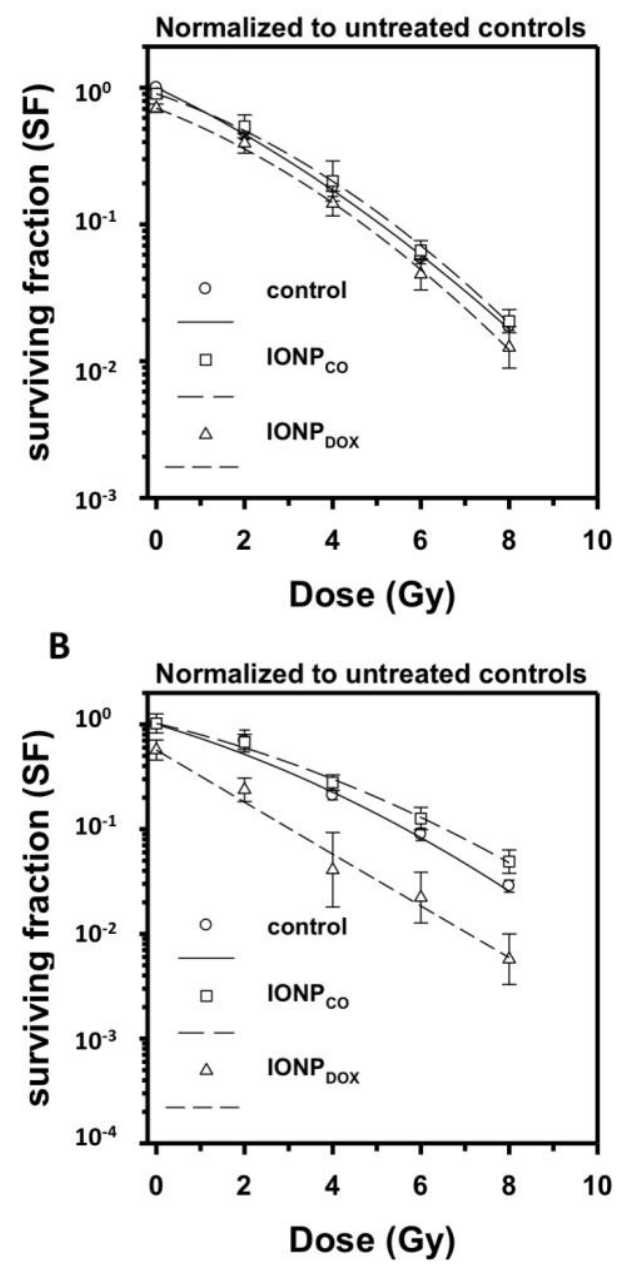
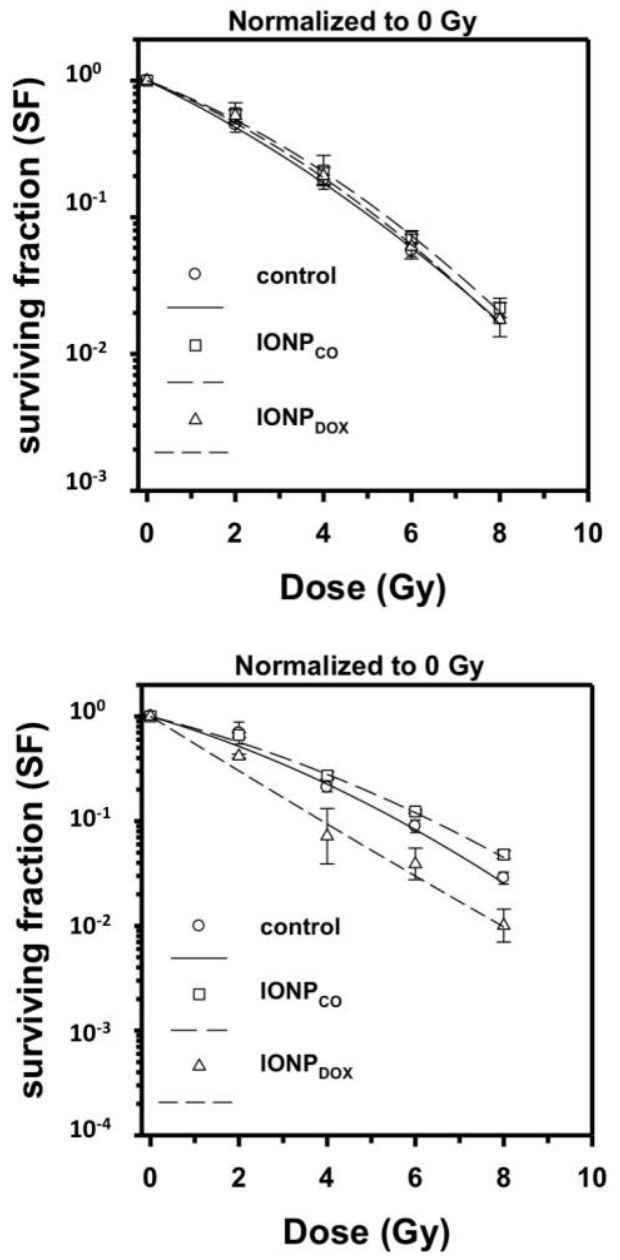

Figure 7. Clonogenic survival of HeLa cells after exposure to $10 \mu \mathrm{g} / \mathrm{mL}$ (A) and $100 \mu \mathrm{g} / \mathrm{mL}$ (B) IONPs for $16 \mathrm{~h}$, followed by $6 \mathrm{MV}$ X-ray treatment. Data are presented as mean $\pm \operatorname{SEM}(\mathrm{n}=3)$.

\section{Discussion}

In this study, we evaluated the radio-modulating effects of core-shell IONP $\mathrm{CO}$ and IONP $_{\text {DOx }}$ on human cervical adenocarcinoma (HeLa) cells after exposure to different doses and energies of ionizing radiation. In addition to the clinical relevance of cervical adenocarcinoma, as this type of cancer has a high frequency in the female population of developing countries [39], the HeLa cell line has been extensively used in studies involving novel nanomaterials for anti-cancer therapeutic purposes [15,40-42].

The proliferation results showed that DOX-free PEG-encapsulated iron oxide nanoparticles $\left(\mathrm{IONP}_{\mathrm{CO}}\right.$ ) were biocompatible for human cervical adenocarcinoma cells, with a maximum reduction of cell viability after $96 \mathrm{~h}$ of $19.19 \pm 6.94 \%$ for $100 \mu \mathrm{g} / \mathrm{mL}$ (Figure 4). These observations were confirmed by determining the clonogenic survival of HeLa cells exposed for $16 \mathrm{~h}$ to different concentrations of IONP $\mathrm{CO}_{\mathrm{CO}}$ (Figures 5 and 7 ) and by literature data [43-45]. Such characteristic is mandatory and requested for radiomodulatory applications involving NPs [46].

Tumor cells were incubated for $16 \mathrm{~h}$ with IONP and then irradiated. This time of interaction between NPs and HeLa cells is shorter than one normal complete cell cycle and sufficient to prevent a possible dilution of internalized NPs due to cell division [47]. In addition, our previous results [38] showed high concentrations of nanoparticles internalized 
during this timeframe using concentrations of $100 \mu \mathrm{g} I \mathrm{IONP} / \mathrm{mL}: 31.66 \pm 3.06 \mathrm{pg} \mathrm{Fe}_{3} \mathrm{O}_{4} /$ cell in case of $\mathrm{IONP}_{\mathrm{CO}}$ and115.2 $\pm 9.8 \mathrm{pg} \mathrm{\textrm {Fe } _ { 3 } \mathrm { O } _ { 4 } / \text { cell for IONP }}$ DOX.

Both low- $(50 \mathrm{kV})$ and high- $(6 \mathrm{MV})$ energy $\mathrm{X}$-ray sources were explored, as having different clinical relevance $[48,49]$ and yielding a different amount of secondary electrons after their interaction with matter. It has been previously shown that the dosemodifying factor is higher at lower energies, and optimum radiosensitization occurs in the $\mathrm{kV}$ range [25,41,50-52]. Our results confirmed a moderate radiosensitizing effect of $\mathrm{IONP}_{\mathrm{CO}}$ at $50 \mathrm{kV}$ and no significant effect of $6 \mathrm{MV}$ X-rays. These modest effects are consistent with Monte Carlo simulations [46] showing that iron oxide nanoparticles have a lower radiomodulating effect compared to other typically used high- $Z$ nanoparticles, such as gold, gadolinium, or iodine. However, the dose-modifying efficiency increased with nanoparticles concentration and lowering of incident $X$-rays energies. Here, $\mathrm{IONP}_{\mathrm{CO}}$ showed a radiosensitizing effect dependent on nanoparticle concentration and photon energy. Significant effects were noticed at the highest NP concentration $(100 \mu \mathrm{g} / \mathrm{mL})$ and lower energies $(50 \mathrm{kV})$. To the best of our knowledge, there are no other studies involving polyethylene glycol-encapsulated iron oxide nanoparticles used for radiosensitization purposes involving conventional X-ray exposure.

Furthermore, the internalization and localization of the nanoparticles inside cells is a key factor in their radiomodulating efficiency. Considering that the path of secondary electrons is limited from tens of nanometers to few micrometers, depending on the nanoparticles physico-chemical properties and energy of radiation source [25], the radiosensitizing effect is highly dependent on nanoparticle localization inside a cell. Klein et al. [17] have shown that citrate- and malate-coated iron oxide nanoparticles not only have a better stability than bare NPs, but also have the ability to escape the vesicles within which they are internalized and to migrate through the cytoplasm into the endoplasmic reticulum, enhancing cells' response to radiation treatment. Similarly, Hauser et al. [26] reported nanoparticles escaping lysosome membranes that directly influenced the normal functionality of the mitochondria by reactive oxygen production in the cytosol after irradiation.

Incubation with $10 \mu \mathrm{g} / \mathrm{mL}$ IONP $\mathrm{DOX}_{\text {ox }}$ for $16 \mathrm{~h}$ prior to $6 \mathrm{MV}$ X-ray exposure did not induce any significant alteration of the HeLa cells surviving fraction, but $100 \mu \mathrm{g} / \mathrm{mL}$ IONP $_{\text {DOX }}$ followed by $6 \mathrm{MV}$ X-ray irradiation resulted in a significantly increased clonogenic inactivation compared to both DOX-free IONP and control cells, with a $\mathrm{DMF}_{\mathrm{SF} 0.1}=1.30 \pm 0.10$ (excluding the intrinsic cytotoxicity of $\mathrm{IONP}_{\mathrm{DOX}}$ ). These results suggest that the decrease in clonogenic survival measured after IONP $_{\mathrm{DOX}}$ treatment may be due to an interaction of the effects of irradiation with the intracellular released DOX, which is known to interact with and affect the genetic material of the cell and induce the DNA damage response. Our previous results [38] showed that most of the encapsulated DOX was delivered within $24 \mathrm{~h}$, with a complete release at $70 \mathrm{~h}$, independent of the medium $\mathrm{pH}$. Using the same IONP concentration, larger amounts of IONP ${ }_{\mathrm{DOx}}$ than IONPco were internalized by the cells. The effect correlated with the hydrodynamic diameter, which doubled after the loading of the drug.

Other studies have also reported enhanced cytotoxic effects of ionizing radiation obtained using nanoparticle formula drug delivery systems [53-57]. Hamzian et al. [58] developed gemcitabine (GEM)-loaded poly (D, L-lactic-co-glycolic acid) (PLGA)-iron oxide nanoparticles for radiosensitization purposes using $0-7 \mathrm{~Gy}{ }^{60} \mathrm{Co}$ gamma irradiation. Their results showed that the drug delivery system and radiation treatment induced a significant decrease of tetrazolium salt metabolic ability in human breast cancer MCF-7 cells compared to only irradiated cells at 7 days after treatment. These results did indicate a reduced proliferation of the cells receiving both treatments, but no other investigation on the survival of these cells was done. No other reports on drug delivery systems based on polyethylene glycol-encapsulated iron oxide nanoparticles were previously published.

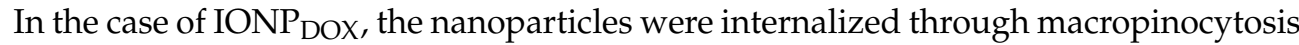
mechanisms, and a high amount appeared free in the cytoplasm, eventually located in the peri-nuclear area (Figure 3B,C,E,F). These NPs are organized in clusters of $160 \mathrm{~nm}$ 
composed of about $20 \mathrm{~nm}$-PEG individually covered iron oxide cores (Figure 1). Similarly, other studies reported significant radiosensitization for NPs organized in clusters rather than single nanoparticles $[26,40,58,59]$.

One of the direct effects of ionizing radiation consists in the alteration of DNA integrity, and $\gamma \mathrm{H} 2 \mathrm{AX}$ foci are an indirect marker of DNA double-strand breaks [60]. Our results

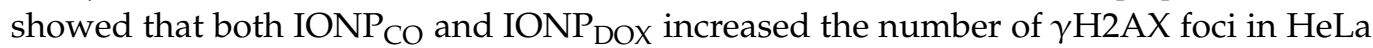
cells without X-ray exposure (Figure 6). As expected, ionizing radiation caused $\gamma \mathrm{H} 2 \mathrm{AX}$ induction, the previous treatment with both $\mathrm{IONP}_{\mathrm{CO}}$ and IONP $\mathrm{DOX}$ causing no significant effect compared to radiation alone $30 \mathrm{~min}$ after radiotherapy (Figure 6). It should be noted that some of the differences observed between the $50 \mathrm{kV}$ and the $6 \mathrm{MV} \mathrm{X}$-ray $\gamma \mathrm{H} 2 \mathrm{AX}$ data are most likely related to the difference in the seeding/irradiation procedure between the two groups (see materials and methods section).

Similar observations were made by Stefancikova et al. [61] who used gadoliniumbased nanoparticles for the radiosensitization of glioblastoma cells and showed that the effects correlated with lysosome disintegration caused nanoparticles liberation into the cytoplasm. Our observations on IONP $\mathrm{DOX}_{\mathrm{DO}}$ behavior in HeLa cells, considering the internalization and localization of the NPs in the cytoplasm of the cells in the peri-nuclear area, the diminished clonogenic survival following additional radiation exposure, and the ability of the cells to repair the genome following both treatments, indicate that the cytotoxicity mechanisms of $\mathrm{IONP}_{\mathrm{DOx}}$ and radiotherapy are beyond the induction of direct DNA damage.

\section{Materials and Methods}

\subsection{Nanoparticle Synthesis and Characterization}

Core-shell iron oxide nanoparticles encapsulated in polyethylene glycol (molecular weight $6 \mathrm{kDa}$ ) were generated using a two-step co-precipitation method as described previously [38]. Bare iron oxide nanoparticles were synthesized using a chemical coprecipitation method at room temperature. The resulting nanoparticles were encapsulated in polyethylene glycol $6000 \mathrm{Da}$ using a 1:1 polymer/nanoparticles ratio, in an anhydrous medium [38].

The resulted nano-constructs $\left(\mathrm{IONP}_{\mathrm{CO}}\right.$ ) with a hydrodynamic diameter of $164.2 \mathrm{~nm}$ (polydispersity index (PDI) of 0.233 and zeta potential of $14.8 \mathrm{mV}$ ), were used to load the chemotherapeutic doxorubicin (DOX, IONP $\mathrm{DOX}$ ), resulting in nanoparticles with a mean diameter of $369.1 \mathrm{~nm}$ (PDI 0.238 and zeta potential of $-20.9 \mathrm{mV}$ ) [38]. The loading of the drug was carried out in an aqueous solution overnight, through ad/absorption [38]. The loaded quantity was $1.11 \mathrm{wt} \%$ DOX [38].

The nanoparticles were characterized using a Tecnai G2 F30 S-TWIN HR-TEM (Thermo Fisher Scientific, Hillsboro, OR, USA), equipped with a selected-area electron diffraction (SAED).

\subsection{Cell Culture}

The biological evaluation of the IONP was performed in human cervical adenocarcinoma cells HeLa (obtained from the Tumor Cell Bank of the German Cancer Research Center (DKFZ, Heidelberg, Germany)), which were cultured in Dulbecco's modified Eagle's medium (DMEM; Biochrom, Merck Millipore, Darmstadt, Germany) supplemented with 10\% FBS (Biochrom, Merck Millipore, Darmstadt, Germany). Cell cultures were maintained at $37^{\circ} \mathrm{C}$ in a humidified incubator $\left(95 \%\right.$ air, $5 \% \mathrm{CO}_{2}$ ). The authenticity of the cell line was confirmed using STR profiling (100\% identical to the ATCC STR database; Cell lines service $\mathrm{GmbH}$, Eppelheim, Germany).

\subsection{Treatment of Cells with IONP}

HeLa cells at different concentrations were seeded and incubated for $4 \mathrm{~h}$ to allow their attachment. After this time, the culture medium was replaced with IONP-containing fresh medium $(10,100 \mu \mathrm{g} / \mathrm{mL}$ nanoparticles), and the cells were incubated for another $16 \mathrm{~h}$. 


\subsection{Detection of IONP Internalization}

$2 \times 10^{5} \mathrm{HeLa}$ cells/well were seeded in 6-well plates and treated as described above. Following the incubation with IONP, the cells were washed several times with PBS, seeded on $10 \mathrm{~mm}$ glass slides, and allowed to adhere for another $24 \mathrm{~h}$. After this period of time, the cells were fixed with $3.7 \%$ PFA. IONP were stained with Prussian blue (1:1 solution of $1 \mathrm{M} \mathrm{HCl}$ and $5 \%$ potassium ferrocyanide), at $37^{\circ} \mathrm{C}$ for $15 \mathrm{~min}$. The visualization was done using optical microscopy, while imaging was performed by fluorescence microscopy taking advantage of DOX native fluorescence. DAPI counterstaining of nuclei was applied.

For the electron microscopy imaging, the cells were fixed with $3.7 \%$ PFA for $24 \mathrm{~h}$ immediately after IONP treatment. Then the cells were detached with a cell scraper and collected in PBS. Staining was performed using a $2 \% \mathrm{OsO}_{4}$ solution (Plano $\mathrm{GmbH}$, Wetzlar, Germany) for $1 \mathrm{~h}$, and dehydration of the cells using ethanol and acetone (Carl Roth GmbH\&Co. KG, Karlsruhe, Germany) solutions at increasing concentrations. Embedding of the samples was done in Epon (SERVA Electrophoresis GmbH, Heidelberg, Germany). $90 \mathrm{~nm}$ slices were placed on copper grids (Plano $\mathrm{GmbH}$ ) and counterstained with uranyl acetate (SERVA Electrophoresis $\mathrm{GmbH}$ ) followed by lead citrate (Merck KGaA, Darmstadt, Germany). Imaging of IONP-treated HeLa cells was performed using a Zeiss EM 10 transmission electron microscope (ZEISS, Oberkochen, Germany), equipped with an Olympus Megaview G2 camera (Olympus Europa SE \& Co. KG, Hamburg, Germany).

\subsection{Proliferation Assay}

The proliferation of HeLa cells following IONP treatment was measured using the MTT tetrazolium-salt viability assay (Sigma-Aldrich Chemie GmbH, Darmstadt, Germany). Cell suspensions at different concentrations $\left(3 \times 10^{3}\right.$, respectively $1.5 \times 10^{3}$ cells/well $)$ were put in 96-well plates avoiding confluency. The IONP treatment was applied as described above, and the cells were incubated during 48,72 , and $96 \mathrm{~h}$. After each time point, the cells were incubated for another $2 \mathrm{~h}$ in presence of $10 \mu \mathrm{g} / \mathrm{mL}$ MTT ( $5 \mathrm{mg} / \mathrm{mL}$ in PBS), and the resulting formazan crystals were solubilized using DMSO. The absorbance of each corresponding sample was measured at $570 \mathrm{~nm}$ using a Tecan infinite M200 microplate reader (Tecan Group Ltd., Männedorf, Switzerland).

\subsection{In Vitro Irradiation}

$50 \mathrm{kV}$ X-rays were generated using a miniature $\mathrm{x}$-ray source (PRS400 of the Intrabeam ${ }^{\circledR}$ system; $50 \mathrm{kV} / 40 \mathrm{~mA}$ ) equipped with a $4 \mathrm{~cm}$ spherical applicator for tumor-bed irradiation (Zeiss Surgical GmbH, Oberkochen, Germany). The dose rate distribution at the cell plane $(0.49 \mathrm{~Gy} / \mathrm{min})$ in water-equivalent phantom [62] was determined by film dosimetry (GafChromic EBT, Wilmington, NJ, USA).

$6 \mathrm{MV}$ X-rays were obtained from a clinical linear accelerator (Versa HD, Elekta Synergy, Stockholm, Sweden) at a dose rate of $6.67 \mathrm{~Gy} / \mathrm{min}$, using a $40 \times 40 \mathrm{~cm}^{2}$ irradiation field. The samples were irradiated at a $100 \mathrm{~cm}$ source-surface distance with $15 \mathrm{~mm}$ water-equivalent material for dose buildup and $8 \mathrm{~cm}$ for backscatter. Dosimetry was performed by the staff medical physicists of the radiotherapy department as part of the daily quality checks.

\subsection{Clonogenic Survival Assay}

Samples for the colony formation assay (CFA) were prepared by seeding $10^{5} \mathrm{HeLa}$ cells/well in 24-well plates. IONP treatment was done as described above. After the incubation time, the cells were carefully washed 3 times with PBS. Cells were detached, and different dilutions of each sample were made (200-5000 cells $/ \mathrm{T}_{25}$ flask). Following irradiation, the cells were seeded at their respective densities using $5 \mathrm{~mL}$ of complete culture medium and incubated in standard conditions of temperature and humidity for 14 days. After this time, the samples were fixed using a methanol and acetic acid solution and stained using crystal violet, as reported [62]; counting and scoring was done as previously described [40]. The surviving fraction (SF) was fitted using a linear-quadratic model 
$\left(\ln (S F)=-\left(\alpha D+\beta D^{2}\right)\right)$, using the non-linear regression tool of SigmaPlot 11 (Systat Software GmbH, Erkrath, Germany) [40].

\section{8. $\gamma H 2 A X$ Foci Detection}

For the $6 \mathrm{MV}$ radiation treatment, $2 \times 10^{5}$ cells/well were seeded in 8-well chamber slides (Falcon, Corning Life Sciences, Amsterdam, The Netherlands) and treated with IONP as described above. The cells were then carefully washed 3 times with PBS and covered with $200 \mu \mathrm{L}$ of nanoparticles-free culture medium. In the case of irradiation with $50 \mathrm{kV} \mathrm{X-rays,} \mathrm{samples} \mathrm{were} \mathrm{prepared} \mathrm{as} \mathrm{for} \mathrm{the} \mathrm{clonogenic} \mathrm{survival} \mathrm{assay} \mathrm{and} \mathrm{irradiated}$ with 0 and $4 \mathrm{~Gy}$. Cells exposed to $50 \mathrm{kV}$ X-rays were attached to the slides using cytospin centrifugation (Thermo Shandon Cytospin 3, Walthman, MA, USA) immediately after irradiation. Fixing was done after $30 \mathrm{~min}, 24 \mathrm{~h}$ from irradiation using 3.7\% PFA; nonspecific binding was reduced by blocking with $1 \%$ BSA in PBST for $10 \mathrm{~min}$; afterwards, the cells were incubated with anti- $\gamma \mathrm{H} 2 \mathrm{AX}$ antibodies (Abcam, Cambridge, UK) for $1 \mathrm{~h}$, at room temperature; donkey anti-mouse FITC-labelled secondary antibodies (Abcam, Cambridge, UK) were used for visualizing $\gamma \mathrm{H} 2 \mathrm{AX}$ foci. Images were acquired using a Leica DMRE microscope equipped with a Leica DFC3000G camera, and counting was performed manually.

\subsection{Statistical Analysis}

All experiments were performed at least in triplicate, and data are presented as mean \pm SEM, unless otherwise noted. Statistical analysis was done using a two-sided Student $t$-test, and one- and two-ways ANOVA (SigmaPlot 11, Systat Software GmbH, Erkrath, Germany).

\section{Conclusions}

This study evaluated the effect of both DOX-free and DOX-loaded polyethylene glycol-encapsulated iron oxide nanoparticles on the clonogenic survival of human cervical adenocarcinoma (HeLa) cells after exposure to low- $(50 \mathrm{kV})$ and high- $(6 \mathrm{MV})$ energy $\mathrm{X}$-rays. IONP $\mathrm{CO}$ proved a radiosensitizing effect dependent on NPs concentration and energy of the X-rays. $\mathrm{IONP}_{\mathrm{CO}}$ showed a significant radiosensitizing effect with $50 \mathrm{kV}$ X-rays. Incubation with $100 \mu \mathrm{g} / \mathrm{mL} \mathrm{IONP}_{\mathrm{DOx}}$ prior to $6 \mathrm{MV}$ X-ray exposure resulted in a significantly increased clonogenic inactivation compared to both $\mathrm{IONP}_{\mathrm{CO}}$ and control cells. The observed radiomodulatory effect of the IONP was not related to changes in DNA double-strand break induction. These results showcase the potential of IONP in bimodal chemo- and radiotherapy of tumor cells.

Author Contributions: Conceptualization, R.C.P., M.R.V. and C.H.; methodology, M.R.V., C.H. and D.I.S.; material characterization, B.S.V.; in vitro investigation, R.C.P., M.B., A.G. and H.H.; resources, F.S.; data curation, R.C.P., M.R.V., C.H. and D.I.S.; writing-original draft preparation, R.C.P. and M.R.V.; writing-review and editing, R.C.P., M.R.V., C.H. and D.I.S.; supervision, M.R.V., C.H., D.I.S. and E.A.; project administration, F.W. and F.A.G.; funding acquisition, M.R.V., C.H., R.C.P., E.A., D.I.S. and F.W. All authors have read and agreed to the published version of the manuscript.

Funding: This research was funded by Deutscher Akademischer Austauschdienst (DAAD) Research grant for doctoral candidates and young academics and scientists No. 57299291, by the Romanian Ministry of Research National grants no. PN 19060203, 64PCCDI/2018, 543PED/2019 and the Romanian Ministry of Foreign Affairs POSCCE-A2-O2.2.1-2013-1/Priority Axe 2, Project no 638/12.03.2014, ID 1970, SMIS-CSNR code 48652.

Conflicts of Interest: The authors declare no conflict of interest.

\section{References}

1. Chen, S.H.; Lahav, G. Two is better than one; toward a rational design of combinatorial therapy. Curr. Opin. Struct. Biol. 2016, 41, 145-150. [CrossRef] [PubMed]

2. Tran, S.; DeGiovanni, P.J.; Piel, B.; Rai, P. Cancer nanomedicine: A review of recent success in drug delivery. Clin. Transl. Med. 2017, 6, 44. [CrossRef] 
3. Zeng, J.; Wu, J.; Li, M.; Wang, P. A Novel Magnetic Nanoparticle for Early Detection of Amyloid Plaques in Alzheimer's Disease. Arch. Med. Res. 2018, 49, 282-285. [CrossRef]

4. Amag Pharmaceuticals. Available online: https://www.amagpharma.com/our-products/ (accessed on 22 June 2020).

5. Grauer, O.; Jaber, M.; Hess, K.; Weckesser, M.; Schwindt, W.; Maring, S.; Wölfer, J.; Stummer, W. Combined intracavitary thermotherapy with iron oxide nanoparticles and radiotherapy as local treatment modality in recurrent glioblastoma patients. J. Neuro Oncol. 2019, 141, 83-94. [CrossRef]

6. MagForce. Available online: https://www.magforce.com/home/ (accessed on 22 June 2020).

7. Nemala, H.; Thakur, J.S.; Naik, V.M.; Vaishnava, P.P.; Lawes, G.; Naik, R. Investigation of magnetic properties of Fe3O4 nanoparticles using temperature dependent magnetic hyperthermia in ferrofluids. J. Appl. Phys. 2014, 116, 034309. [CrossRef]

8. Kempson, I. Mechanisms of nanoparticle radiosensitization. WIREs Nanomed. Nanobiotechnol. 2020, 13, e1656. [CrossRef] [PubMed]

9. Su, X.Y.; Liu, P.D.; Wu, H.; Gu, N. Enhancement of radiosensitization by metal-based nanoparticles in cancer radiation therapy. Cancer Biol. Med. 2014, 11, 86-91. [PubMed]

10. Schuemann, J.; Berbeco, R.; Chithrani, D.B.; Cho, S.H.; Kumar, R.; McMahon, S.J.; Sridhar, S.; Krishnan, S. Roadmap to Clinical Use of Gold Nanoparticles for Radiation Sensitization. Int. J. Radiat. Oncol. Biol. Phys. 2016, 94, 189-205. [CrossRef] [PubMed]

11. Liu, Y.; Zhang, P.; Li, F.; Jin, X.; Li, J.; Chen, W.; Li, Q. Metal-based NanoEnhancers for Future Radiotherapy: Radiosensitizing and Synergistic Effects on Tumor Cells. Theranostics 2018, 8, 1824-1849. [CrossRef]

12. Rashid, R.A.; Abidin, S.Z.; Anuar, M.A.K.; Tominaga, T.; Akasaka, H.; Sasaki, R.; Kie, K.; Razak, K.A.; Pham, B.T.T.; Hawkett, B.S.; et al. Radiosensitization effects and ROS generation by high Z metallic nanoparticles on human colon carcinoma cell (HCT116) irradiated under $150 \mathrm{MeV}$ proton beam. OpenNano 2019, 4, 100027. [CrossRef]

13. Kobayashi, K.; Usami, N.; Porcel, E.; Lacombe, S.; Le Sech, C. Enhancement of radiation effect by heavy elements. Mutat. Res. 2010, 704, 123-131. [CrossRef] [PubMed]

14. Lechtman, E.; Pignol, J.P. Interplay between the gold nanoparticle sub-cellular localization, size, and the photon energy for radiosensitization. Sci. Rep. 2017, 7, 13268. [CrossRef]

15. Zhang, X.D.; Wu, D.; Shen, X.; Chen, J.; Sun, Y.M.; Liu, P.X.; Liang, X.J. Size-dependent radiosensitization of PEG-coated gold nanoparticles for cancer radiation therapy. Biomaterials 2012, 33, 6408-6419. [CrossRef]

16. Ma, N.; Wu, F.G.; Zhang, X.; Jiang, Y.-W.; Jia, H.-R.; Wang, H.-Y.; Li, Y.-H.; Liu, P.; Gu, N.; Chen, Z. Shape-Dependent Radiosensitization Effect of Gold Nanostructures in Cancer Radiotherapy: Comparison of Gold Nanoparticles, Nanospikes, and Nanorods. ACS Appl. Mater. Interfaces 2017, 9, 13037-13048. [CrossRef] [PubMed]

17. Klein, S.; Sommer, A.; Distel, L.V.R.; Hazemann, J.L.; Kröner, W.; Neuhuber, W.; Müller, P.; Proux, O.; Kryschi, C. Superparamagnetic Iron Oxide Nanoparticles as Novel X-ray Enhancer for Low-Dose Radiation Therapy. J. Phys. Chem. B 2014, 118, 6159-6166. [CrossRef]

18. Hosseini, V.; Mirrahimi, M.; Shakeri-Zadeh, A.; Koosha, F.; Ghalandari, B.; Maleki, S.; Komeili, A.; Kamrava, S.K. Multimodal cancer cell therapy using $\mathrm{Au} @ \mathrm{Fe}_{2} \mathrm{O}_{3}$ core-shell nanoparticles in combination with photo-thermo-radiotherapy. Photodiagnosis Photodyn. Ther. 2018, 24, 129-135. [CrossRef]

19. Gong, F.; Chen, J.; Han, X.; Zhao, J.; Wang, M.; Feng, L.; Li, Y.; Liu, Z.; Cheng, L. Core-shell TaOx@MnO2 nanoparticles as nano-radiosensitizer for effective cancer radiotherapy. J. Mater. Chem. B 2018, 6, 2250-2257. [CrossRef]

20. Li, M.; Zhao, Q.; Yi, X.; Zhong, X.; Song, G.; Chai, Z.; Liu, Z.; Yang, K. Au@MnS@ZnS Core/Shell/Shell Nanoparticles for Magnetic Resonance Imaging and Enhanced Cancer Radiation Therapy. ACS Appl. Mater. Interfaces 2016, 8, 9557-9564. [CrossRef]

21. Shetake, N.G.; Kumar, A.; Pandey, B.N. Iron-oxide nanoparticles target intracellular HSP90 to induce tumor radio-sensitization. Biochim. Biophys. Acta Gen. Subj. 2019, 1863, 857-869. [CrossRef] [PubMed]

22. Kang, B.; Mackey, M.A.; El-Sayed, M.A. Nuclear Targeting of Gold Nanoparticles in Cancer Cells Induces DNA Damage, Causing Cytokinesis Arrest and Apoptosis. J. Am. Chem. Soc. 2010, 132, 1517-1519. [CrossRef]

23. Fan, W.; Shen, B.; Bu, W.; Zheng, X.; He, Q.; Cui, Z.; Zhao, K.; Zhang, S.; Shi, J. Design of an intelligent sub-50 nuclear targeting nanotheranostic system for imaging guided intranuclear radiosensitization. Chem. Sci. 2015, 6, 1747-1753. [CrossRef] [PubMed]

24. Fang, X.; Wang, Y.; Ma, X.; Zhang, Z.; Xiao, Z.; Liu, L.; Gao, X.; Liu, J. Mitochondria-targeting Au nanoclusters enhance radiosensitivity of cancer cells. J. Mater. Chem. B 2017, 5, 4190-4197. [CrossRef] [PubMed]

25. Retif, P.; Pinel, S.; Toussaint, M.; Frochot, C.; Chouikrat, R.; Bastogne, T.; Barberi-Heyob, M. Nanoparticles for Radiation Therapy Enhancement: The Key Parameters. Theranostics 2015, 5, 1030-1044. [CrossRef] [PubMed]

26. Hauser, A.; Mitov, M.I.; Daley, E.F.; McGarry, R.C.; Anderson, K.W.; Hilt, J.Z. Targeted iron oxide nanoparticles for the enhancement of radiation therapy. Biomaterials 2016, 105, 127-135. [CrossRef] [PubMed]

27. National Library of Medicine. Post Operative Chemoradiation for Extremity \& Trunk Soft Tissue Sarcoma. Available online: https:/ / clinicaltrials.gov / ct2/ show / NCT00502411?term=radiation+doxorubicin\&rank=2 (accessed on 21 June 2021).

28. National Library of Medicine. Doxorubicin Plus External-Beam Radiation Therapy in Treating Patients with Soft Tissue Sarcoma. Available online: https:/ / clinicaltrials.gov/ct2/show / NCT00004109?term=radiation+doxorubicin\&rank=5 (accessed on 21 June 2021).

29. National Library of Medicine. Radiation Therapy Plus Doxorubicin in Treating Patients with Resectable Primary or Recurrent Retroperitoneal Soft Tissue Sarcoma. Available online: https://clinicaltrials.gov/ct2/show/NCT00004123?term=radiation+ doxorubicin (accessed on 21 June 2021). 
30. National Library of Medicine. Combination Chemotherapy Plus Radiation Therapy in Treating Patients with Stage III or Stage IV Endometrial Cancer. Available online: https: / clinicaltrials.gov/ct2/show /NCT00005830?term=radiation+doxorubicin\&rank=6 (accessed on 21 June 2021).

31. National Library of Medicine. Hypofractionated Radiotherapy with Sequential Chemotherapy in Primary Unresectable or Marginally Resectable Soft Tissue Sarcomas of Extremities or Trunk Wall (UN-RESARC). Available online: https: / clinicaltrials. gov / ct2/show / NCT03651375?term=radiation+doxorubicin\&rank=7 (accessed on 21 June 2021).

32. Rosenthal, C.J.; Rotman, M. Pilot study of interaction of radiation therapy with doxorubicin by continuous infusion. NCI Monogr. 1988, 6, 285-290.

33. Vinin, N.V.; Prem, S.S.; Pillai, A.; Reddy, K.S.; Dhanapathi, H.; Sudhakar, K. Early Cardiac Changes Due to Doxorubicin based Chemotherapy and Radiotherapy in Early and Locally Advanced Carcinoma Breast Patients: An Observational Study. J. Nucl. Med. Radiat. Ther. 2015, S7, 004.

34. Shapiro, C.L.; Hardenbergh, P.H.; Gelman, R.; Blanks, D.; Hauptman, P.; Recht, A.; Hayes, D.F.; Harris, J.; Henderson, I.C. Cardiac effects of adjuvant doxorubicin and radiation therapy in breast cancer patients. J. Clin. Oncol. 1998, 16, 3493-3501. [CrossRef]

35. Hardenbergh, P.H.; Recht, A.; Gollamudi, S.; Come, S.E.; Hayes, D.F.; Shulman, L.N.; O’Neill, A.; Gelman, R.S.; Silver, B.; Harris, J.R. Treatment-related toxicity from a randomized trial of the sequencing of doxorubicin and radiation therapy in patients treated for early stage breast cancer. Int. J. Radiat. Oncol. Biol. Phys. 1999, 45, 69-72. [CrossRef]

36. Toma, S.; Palumbo, R.; Sogno, G.; Barra, S.; Canavese, G.; Castagneto, B.; Frola, C.; Aitini, E.; Rosso, R. Concomitant radiationDoxorubicin administration in locally advanced and/or metastatic soft tissue sarcomas. Anticancer Res. 1991, 11, 2085-2089.

37. Longhi, A.; Ferrari, S.; Tamburini, A.; Luksch, R.; Fagioli, F.; Bacci, G.; Ferrari, C. Late effects of chemotherapy and radiotherapy in osteosarcoma and Ewing sarcoma patients. The Italian Sarcoma Group Experience (1983-2006). Cancer 2012, 118, 5050-5059. [CrossRef]

38. Popescu, R.C.; Savu, D.; Dorobantu, I.; Vasile, B.S.; Hosser, H.; Boldeiu, A.; Temelie, M.; Straticiuc, M.; Iancu, D.A.; Andronescu, E.; et al. Efficient uptake and retention of iron oxide-based nanoparticles in HeLa cells leads to an effective intracellular delivery of doxorubicin. Sci. Rep. 2020, 10, 10530. [CrossRef]

39. World Health Organization. Cervical Cancer. Available online: https:/ /www.who.int/health-topics/cervical-cancer (accessed on 14 June 2021).

40. Burger, N.; Biswas, A.; Barzan, D.; Kirchner, A.; Hosser, H.; Hausmann, M.; Hildenbrand, G.; Herskind, C.; Wenz, F.; Veldwijk, M.R. A method for the efficient cellular uptake and retention of small modified gold nanoparticles for the radiosensitization of cells. Nanomed. NBM 2014, 10, 1365-1373. [CrossRef]

41. Chithrani, D.B.; Jelveh, S.; Jalali, F.; van Prooijen, M.; Allen, C.; Bristow, R.G.; Hill, R.P.; Jaffray, D.A. Gold nanoparticles as radiation sensitizers in cancer therapy. Radiat. Res. 2010, 173, 719-728. [CrossRef] [PubMed]

42. Berbeco, R.I.; Korideck, H.; Ngwa, W.; Kumar, R.; Patel, J.; Sridhar, S.; Johnson, S.; Price, B.D.; Kimmelman, A.; Makrigiorgos, G.M. DNA damage enhancement from gold nanoparticles for clinical MV photon beams. Radiat. Res. 2012, 178, 604-608 [CrossRef] [PubMed]

43. Gang, Y.; Yuan, Y.; Xu, K.; Luo, Q. Biocompatible PEGylated $\mathrm{Fe}_{3} \mathrm{O}_{4}$ Nanoparticles as Photothermal Agents for Near-Infrared Light Modulated Cancer Therapy. Int. J. Mol. Sci. 2014, 15, 18776-18788.

44. Kansara, K.; Patel, P.; Shukla, R.K.; Pandya, A.; Shanker, R.; Kumar, A.; Dhawan, A. Synthesis of biocompatible iron oxide nanoparticles as a drug delivery vehicle. Int. J. Nanomed. 2018, 13, 79-82. [CrossRef] [PubMed]

45. Liu, Y.; Liu, X.; Jin, X.; He, P.; Zheng, X.; Dai, Z.; Ye, F.; Zhao, T.; Chen, W.; Li, Q. The dependence of radiation enhancement effect on the concentration of gold nanoparticles exposed to low- and high-LET radiations. Phys. Med. 2015, 31, 210-218. [CrossRef]

46. Hwang, C.; Kim, L.M.; Kim, J.H. Influence of concentration, nanoparticle size, beam energy and material on dose enhancement in radiation therapy. J. Radiat. Res. 2017, 58, 405-411. [CrossRef] [PubMed]

47. Kim, J.A.; Aberg, C.; Salvati, A.; Dawson, K.A. Role of cell cycle on the cellular uptake and dilution of nanoparticles in a cell population. Nat. Nanotechnol. 2012, 7, 62-68. [CrossRef] [PubMed]

48. Herskind, C.; Ma, L.; Liu, Q.; Zhang, B.; Schneider, F.; Veldwijk, M.R.; Wenz, F. Biology of high single doses of IORT: RBE, 5 R's, and other biological aspects. Radiat. Oncol. 2017, 12, 24. [CrossRef] [PubMed]

49. Sethi, A.; Emami, B.; Small, W.; Thomas, T.O. Intraoperative Radiotherapy with INTRABEAM: Technical and Dosimetric Considerations. Front. Oncol. 2018, 8, 74. [CrossRef] [PubMed]

50. Rahman, W.N.; Corde, S.; Yagi, N.; Abdul Aziz, S.A.; Annabell, N.; Geso, M. Optimal energy for cell radiosensitivity enhancement by gold nanoparticles using synchrotron-based monoenergetic photon beams. Int. J. Nanomed. 2014, 9, $2459-2467$. [CrossRef] [PubMed]

51. Rahman, W.N.; Bishara, N.; Ackerly, T.; He, C.F.; Jackson, P.; Wong, C.; Davidson, R.; Geso, M. Enhancement of radiation effects by gold nanoparticles for superficial radiation therapy. Nanomedicine 2009, 5, 136-142. [CrossRef] [PubMed]

52. Jain, S.; Coulter, J.A.; Hounsell, A.R.; Butterworth, K.T.; McMahon, S.J.; Hyland, W.B.; Muir, M.F.; Dickson, G.R.; Prise, K.M.; Currell, F.J.; et al. Cell-specific radiosensitization by gold nanoparticles at megavoltage radiation energies. Int. J. Radiat. Oncol. Biol. Phys. 2011, 79, 531-539. [CrossRef] [PubMed]

53. Starkewolf, Z.B.; Miyachi, L.; Wong, J.; Guo, T. X-ray triggered release of doxorubicin from nanoparticle drug carriers for cancer therapy. Chem. Commun. 2013, 49, 2545-2547. [CrossRef] [PubMed] 
54. Li, T.; Zhang, M.; Wang, J.; Wang, T.; Yao, Y.; Zhang, X.; Zhang, C.; Zhan, N. Thermosensitive Hydrogel Co-loaded with Gold Nanoparticles and Doxorubicin for Effective Chemoradiotherapy. AAPS J. 2015, 18, 146-155. [CrossRef]

55. Xu, W.H.; Han, M.; Dong, Q.; Fu, Z.X.; Diao, Y.Y.; Liu, H.; Xu, J.; Jiang, H.L.; Zhang, S.Z.; Zheng, S.; et al. Doxorubicin-mediated radiosensitivity in multicellular spheroids from a lung cancer cell line is enhanced by composite micelle encapsulation. Int. J. Nanomed. 2012, 7, 2661-2671.

56. Shi, W.; Yuan, Y.; Chu, M.; Zhao, S.; Song, Q.; Mu, X.; Xu, S.; Zhang, Z.; Yang, K. Radiosensitization of TPGS-emulsified doxetaxelloaded poly(lactic-co-glycolic acid) nanoparticles in CNE-1 and A549 cells. J. Biomater. Appl. 2016, 30, 1127-1141. [CrossRef]

57. Werner, M.E.; Copp, J.A.; Karve, S.; Cummings, N.D.; Sukumar, R.; Li, C.; Napier, M.E.; Chen, R.C.; Cox, A.D.; Wang, A.Z. Folate-Targeted Polymeric Nanoparticle Formulation of Docetaxel Is an Effective Molecularly Targeted Radiosensitizer with Efficacy Dependent on the Timing of Radiotherapy. ACS Nano 2011, 5, 8990-8998. [CrossRef]

58. Hamzian, N.; Hashemi, M.; Ghorbani, M.; Aledavood, S.A.; Ramezani, M.; Bahreyni Toosi, M.H. In vitro Study of Multifunctional PLGA-SPION Nanoparticles Loaded with Gemcitabine as Radiosensitizer Used in Radiotherapy. Iran. J. Pharm. Res. 2019, 18, 1694-1703. [PubMed]

59. Rima, W.; Sancey, L.; Aloy, M.T.; Armandy, E.; Alcantara, G.B.; Epicier, T.; Malchre, A.; Joly-Pottuz, L.; Mowat, P.; Lux, F.; et al. Internalization pathways into cancer cells of gadolinium-based radiosensitizing nanoparticles. Biomaterials 2013, 34, 181-195. [CrossRef] [PubMed]

60. Kuo, L.J.; Yang, L.X. Gamma-H2AX-A novel biomarker for DNA double-strand breaks. In Vivo 2008, 22, 305-309. [PubMed]

61. Stefancikova, L.; Lacombe, S.; Salado, D.; Porcel, E.; Pagáčová, E.; Tillement, O.; Lux, F.; Depeš, D.; Kozubek, S.; Falk, M. Effect of gadolinium-based nanoparticles on nuclear DNA damage and repair in glioblastoma tumor cells. J. Nanobiotechnol. 2016, 14, 63. [CrossRef]

62. Liu, Q.; Schneider, F.; Ma, L.; Wenz, F.; Herskind, C. Relative biologic effectiveness (RBE) of $50 \mathrm{kV}$ x-rays measured in a phantom for intraoperative tumor-bed irradiation. Int. J. Radiat. Oncol. Biol. Phys. 2013, 85, 1127-1133. [CrossRef] [PubMed] 